\title{
Recorregut de recerca geològica i mineralògica per la comarca del Pallars Jussà: des de Senterada a Sarroca de Bellera, a Xerallo i a Benés
}

Josep Maria Mata-Perelló

Joaquim Sanz Balagué

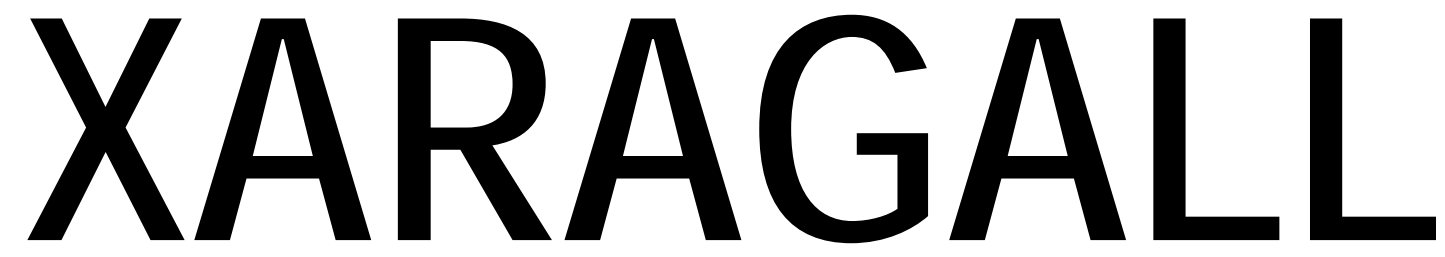

REVISTA DE CIÈNCIES DE LA CATALUNYA CENTRAL

ก. 9

SETEMBRE 2014 


\section{RECORREGUT DE RECERCA GEOLÒGICA I MINERALÒGICA PER LA COMARCA DEL PALLARS JUSSÀ: DES DE SENTERADA A SARROCA DE BELLERA, A XERALLO I A BENÉS}

\section{Josep Maria Mata-Perelló}

Museu de geologia Valentí Masachs, Escola Politècnica Superior d'Enginyeria de Manresa (EPSEM), Universitat Politècnica de Catalunya · BarcelonaTech (UPC), 08272 Manresa, Spain

\section{Joaquim Sanz Balagué}

Departament d'Enginyeria Minera i Recursos Naturals (EMRN), Escola Politècnica Superior d'Enginyeria de Manresa (EPSEM), Universitat Politècnica de Catalunya - BarcelonaTech (UPC), 08272 Manresa, Spain

Paraules clau: Sitema Pirinenc, Unitat de les Nogueres, Patrimoni miner

\section{Resum}

Itinerari realitzat el 21 de setembre de 2013. En aquesta ocasió, la totalitat del recorregut de l'itinerari es desenvoluparà per una sola unitat geològica: concretament pel Sistema Pirinenc, i més exactament per la Unitat de les Nogueres. Tot i així, s'iniciarà molt a prop de l'extrem septentrional del Mantell de Bóixols, que en indrets propers a Sarroca de Bellera i de Xerallo, arribarà a tallar-se.

D’aquesta manera, el recorregut s'iniciarà a la població de (situada a la Unitat de les Nogueres), però molt a prop del Mantell de Bóixols. Així, en el recorregut cap a Sarroca de Bellera i cap a Xerallo, es discorrerà molt a prop del contacte entre les dues unitats anteriors.

Posteriorment, des de Xerallo a les Esglésies, a la Mola d'Amunt i a Benés, tot el recorregut transitarà plenament dintre de la Unitat de les Nogueres.

Per d'altra banda, aquest itinerari es desenvoluparà íntegrament per una comarca, la del Pallars Jussà. Cal dir que aquesta comarca forma part de I'antiga Regió de Tremp - la Seu d’Urgell. 


\section{Objectius fonamentals}

Es centraran en els aspectes geològics, geomorfològics i mineralògics que apuntarem a continuació:

1. Observació dels materials mesozoics i cenozoics que formen part de l'extrem septentrional del Mantell del Bóixols, que veurem per les proximitats meridionals del recorregut entre Senterada i Xerallo. Aquests materials mesozoics pertanyen al Cretàcic i els cenozoic a I’Eocè.

2. Observació i descripció dels materials mesozoics que formen part de la Unitat de Bóixols; que trobarem entre Senterada i les immediacions de Xerallo, per la zona de contacte amb la Zona de les Nogueres, situada més cap al Nord. Els materials mesozoics pertanyen fonamentalment al Cretàcic (amb nivells carbonatats) i al Triàsic (amb nivells de gresos, calcaries, guixos, argiles i ofites, segons els llocs).

3. Observació dels materials que constitueixen la Unitat de les Nogueres. Aquests materials pertanyen al Carbonífer (amb trams d'esquistos negres, fonamentalment) al Permotries (amb gresos rogencs), i sobretot al Triàsic Superior, al Keuper (amb trams de guixos, argiles i ofites).

4. Observació de les relacions existents entre les diferents làmines d'encavalcament, de les dues unitats anteriors. Precisament, com ja hem avançat, una part del recorregut de l'itinerari s'efectuarà per les immediacions de la zona de contacte entre les dues unitats geològiques acabades d'esmentar.

5. Observació de les diferents mineralitzacions que anirem trobant al llarg del recorregut, com les mineralitzacions evaporítiques de GUIX, situades prop del poble de Senterada (Pallars Jussà), entre els materials triàsics del Keuper.

6. Observació al llarg del recorregut de l'itinerari de les antigues explotacions, entre elles de les següents

6a) de les de guix (relacionades amb les mineralitzacions anteriors), situades entre els afloraments triàsics del Keuper de la Unitat de les Nogueres

6b) de les explotacions carbonatades del Cretàcic, (adreçades a l'antiga fàbrica de ciment de Xerallo). Es troben situades entre els afloraments carbonatats cretàcics del Mantell de Bóixols

6c) de les explotacions de gresos rogencs, situades a Xerallo, entre els afloraments triàsics de la Unitat de les Nogueres.

7. Observació de l'impacte produït sobre el Medi Natural, com a conseqüència de les activitats mineres anteriors i també de les obres efectuades per la zona.

8. Observació dels indrets relacionats amb el patrimoni geològic i miner, que es vagin trobant al llarg del recorregut. En especial el de I' antiga fàbrica de ciment de Xerallo. 


\section{Antecedents}

Pel que fa al recorregut del present itinerari, existeixen uns antecedents nostres, relatius a altres itineraris geològic i miners proper al que ara presentem. Aquests antecedents, són: MataPerelló (1995, 1996a, 1996b, 1998a, 1998b, 2000, 2002, 2003, 2005, 2009, 2010 i 2013). També cal fer esment del treball de Mata-Perelló i Montan (2003).

Pel que fa a la descripció de les mineralitzacions, cal parlar d'un altre treball, també nostre; en concret de Mata-Perelló (1991). Aquest treball es relatiu a les mineralitzacions catalanes en general, amb un capítol dedicat a la Noguera. També cal fer esment de Mata-Perelló i Sanz (1993), dedicat al reconeixement dels minerals.

I pel que fa a l'estructura geològica de la zona per la qual discorre l'itinerari, farem esment de dos treballs, molt interessants, de caràcter generalista. En concret, ens estem referint als següents: Guimerà et altri (1982). i també a RIBA et altri (1976). Tots dos treballs es refereixen a la geologia dels Països Catalans, i conseqüentment de Catalunya. Per d'altra banda, també cal fer esment del treball de RosellL (1970); així com de l'IGME (1994).

Tots aquests treballs referenciats, i d'altres, figuren esmentats per ordre alfabètic a l'apartat dedicat a la BIBLIOGRAFIA.

\section{Recorregut de l'itinerari}

El recorregut de l'itinerari discorrerà per dues comarques de la Regió de Tremp - la Seu d'Urgell; concretament per la comarca del Pallars Jussà, per on s'iniciarà i per on finalitzarà el recorregut de l'itinerari.

Així, el recorregut s'iniciarà a la població de Senterada, prop d'on es realitzarà una aturada, si s'escau. Posteriorment, es continuarà per la carretera N-260. Per tal d'anar cap a ponent. Així, aviat es passarà per la població de Sarroca de Bellera, arribant-se després al trencall de Xerallo i les Esglésies, circulant sempre pel contacte entre la Unitat de Bóixols i la Unitat de les Nogueres.

En aquest anterior trajecte s'efectuaran dues aturades, si s'escau. Posteriorment, s'anirà cap a les immediacions de la Mola d'Amunt (prop de la cruilla de Sentis), anant finalment cap a les immediacions de Benés, per on es farà la darrera aturada, finalitzant el recorregut.

\section{Advertiments previs}

Com en altres recorreguts de RECERCA GEOLÒGICA I MINERALÒGICA ..., si es disposa del temps suficient, poden efectuar-se passant per totes les parades i filloles. En cas contrari, recomanem prescindir de les anomenades PARADES - CONDICIONALS.

També cal tenir en conte que una part del recorregut final de l'itinerari, es realitzarà per camins de terra, per la qual cosa caldrà prendre les degudes precaucions, 
Cal tenir, com sempre, una cura molt especial de respecte a la natura, al llarg de tot el recorregut de l'itinerari, i també fora d'ell.

\section{Descripció de l'itinerari}

En aquest recorregut hem situat, com ja és habitual en tots els itineraris, una sèrie d'ESTACIONS o de PARADES, que anirem veient a continuació. En cada cas, els hi donarem una denominació que podrà correspondre a algun paratge proper. També indicarem el terme municipal i la comarca on es troba. Per d'altra banda, en cada una de les parades, indicarem entre parèntesi el número del "Mapa Topográfico", a escala 1:50.000, on es troba situada la parada considerada. En aquesta ocasió serà algun dels següents: 213 (o de Pont de Suert; 214 (o de Sort) i 252 (Tremp).

Així doncs, la relació ordenada de les parades que composen aquest recorregut, és la següent.

\subsection{Parada 1 - CONDICIONAL. GUIXERA DE LES INMEDIACIONES DE LA CASA BLANCA, (terme de Senterada, comarca del Pallars Jussà). (Full 252).}

Tot i que el recorregut, I'iniciarem a la Pobla de Segur, ens caldrà agafar l'actual carretera N260 (''antiga carretera comarcal C-144) per tal d'anar cap a Senterada passant pel Congost d’Erinyà.

En arribar a la població esmentada, ens caldrà sobrepassar-la, seguint sempre per la carretera $\mathrm{N}-260$, seguint des de Senterada la vall del riu Bòssia, remuntant-lo. Després de recórrer poc més de $1 \mathrm{Km}$ des de Senterada, s'arribarà a l'indret on hi ha la Casa Blanca, prop d'on farem aquesta aturada

Aquest indret i pràcticament tot el trajecte fins a la parada, es troba situat a la zona de contacte entre la Unitat de Bóixols (Serra de Sant Gervàsi), situada al Sud, i la Unitat de les Nogueres, situada al Nord. Així, fonamentalment hem trobat afloraments dels nivells de guixos i argiles del Keuper

Precisament, a l'indret de l'aturada hi ha una antiga i petita explotació dels nivells guixosos acabats d'esmentar

\subsection{Parada 2. SORTIDA DE SARROCA DE BELLERA CAP A XERALLO, (Sarroca de Bellera, terme municipal de Sarroca de Bellera, comarca del Pallars Jussà). (Full 252).}

Després de fer la parada anterior, cal continuar cap a ponent per la carretera nacional $\mathrm{N}-260$. Poc després de realitzar la parada anterior, trobarem per la dreta el trencall de Sarroca de Bellera, el qual ens caldrà agafar, la carretera local $L$ - 521. En arribar al poble, després de sobrepassar-lo, podem fer una nova aturada, a uns $5 \mathrm{Km}$ de I'anteriorment realitzada.

En aquest recorregut hem anat circulant per la vall del riu Bòssia, remuntant-lo. Per d'altra banda, hem anat veient el contacte entre la Unitat de les Nogueres, situada al Nord d'on ara som (amb afloraments dels materials triàsics, fonamentalment per aquest indret) i el Mantell de Bóixols, situat al sud d'on ara ens trobem (amb afloraments dels materials cretàcics). 
Precisament, aquests darrers són els que apareixen a l'indret de la present aturada. Aquí es fa clarament pales un aflorament de les roques carbonatades cretàciques, força inclinada. Cal dir que el poble es troba situat al costat d'aquest aflorament, el qual forma una muralla natural entorn del sector meridional, sobre el qual es va edificar el castell del poble.

Com a conseqüència d'aquest aflorament de roques carbonatades, formant una ostensible massa calcària, ha sorgit el nom del poble: "la roca" o "Sarroca". Es doncs una terminologia clarament geològica. (fotografia 2).

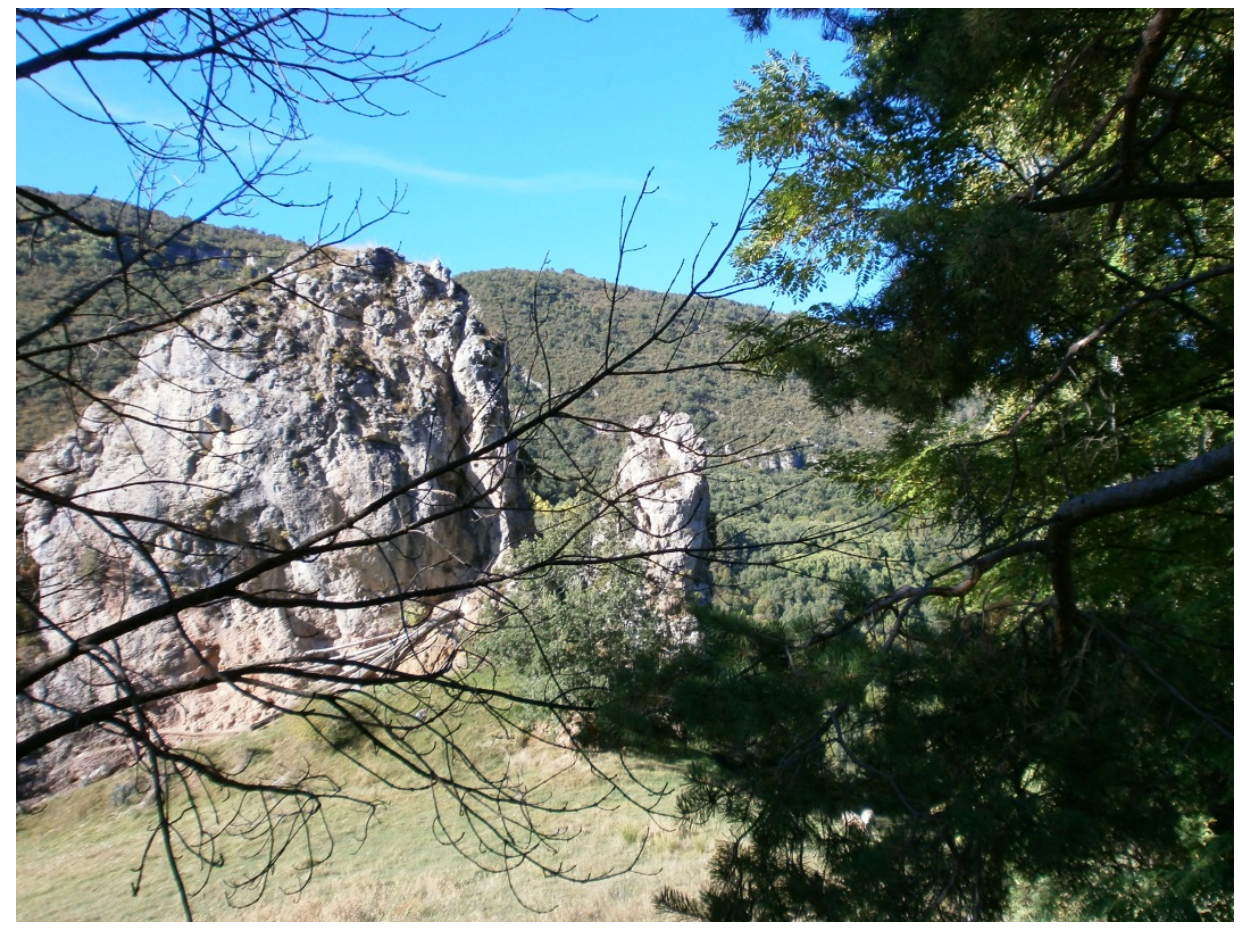

Fotografia 1. Aflorament de les calcàries cretàciques a Sarroca de Bellera: La Roca. Setembre del 2013 


\subsection{Parada 3. RESTES DEL TELEFÈRIC DE LA PEDRERA DE XERALLO, (Xerallo, actual terme de Sarroca de Bellera de la comarca del Pallars Jussà i abans del terme de Benés, de l’Alta Ribagorça). (Full 214).}

Des de la parada anterior, cal fer un breu recorregut cap a ponent per la carretera $L$ - 521 . En aquest recorregut s'arribarà al trencall de Xerallo, cap a on ens caldrà anar. Tot i així, en arribar al trencall, podem fer una nova aturada, a uns $3 \mathrm{Km}$ de l'anteriorment realitzada.

En aquest recorregut hem anat trobant els materials esmentats a la parada anterior. Així, s'han fet força palesos els nivells d'argiles i guixos del Keuper. Més amunt, mirant cap al Nord, també es fan força palesos els trams rogencs del Permotries (fonamental ment amb gresos) i els negrencs del Carbonífer (amb trams d'esquistos). Aquests materials, nosaltres no els tallarem, però es fan palesos al Nord d'on ara som.

En aquest indret hi ha les restes de les pilones del telefèric, per on baixaven les calcàries cap a la fàbrica de ciment que veurem a la parada següent. Aquestes pilones constitueixen un element important del Patrimoni Miner de la Comarca del Pallars Jussà. (fotografía 2).

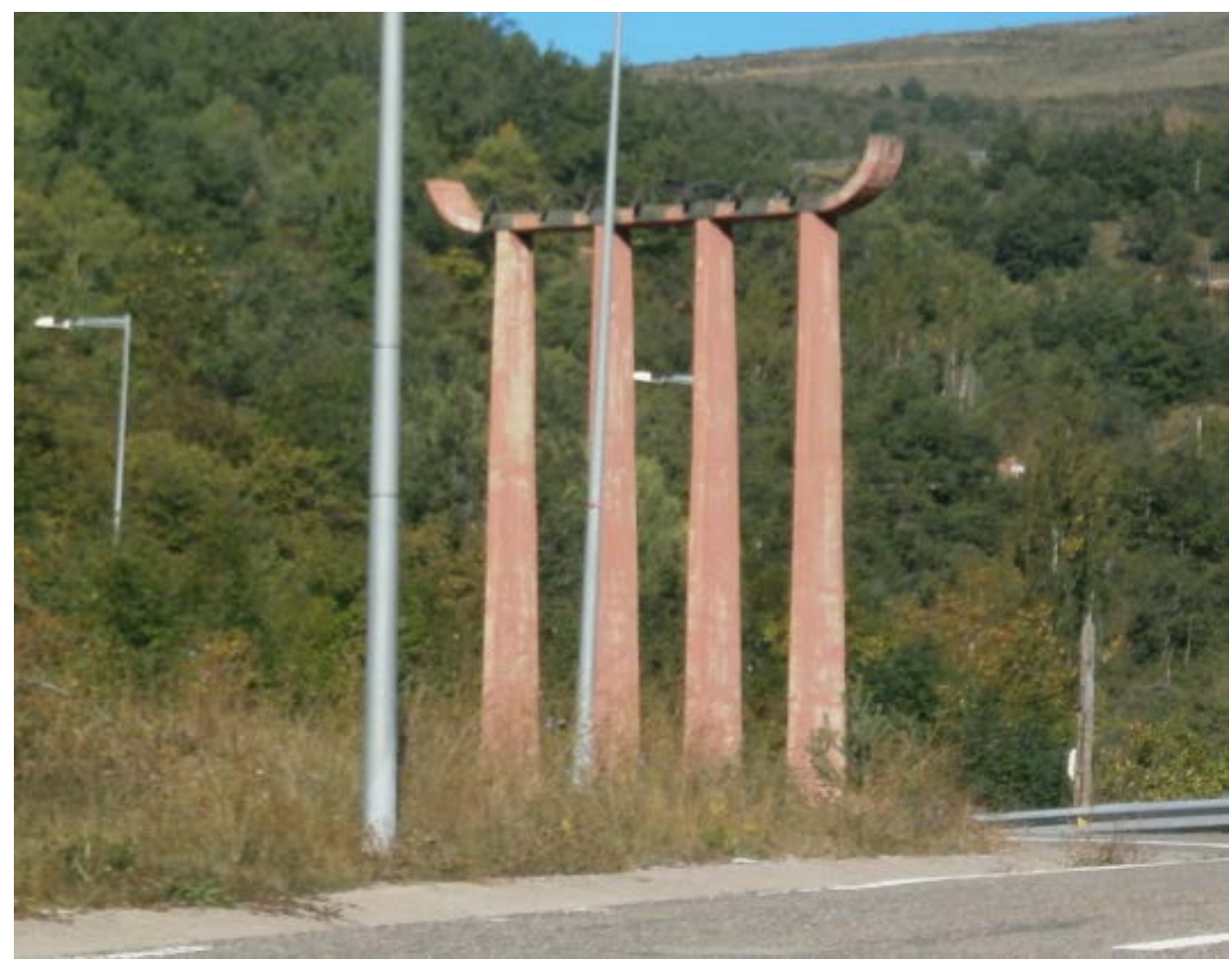

Fotografia 2. Pilones del telefèric de Xerallo, de protecció del seu pas sobre la carretera. Setembre del 2013 


\subsection{Parada 4. ANTIGA FÀBRICA DE CIMENT DE XERALLO, (Xerallo, actual terme de Sarroca de Bellera de la comarca del Pallars Jussà, i antigament del terme de Benés, de I'Alta Ribagorça). (Full 214).}

Després de realitzar la parada anterior, ens cal continuar per la carretera local $L-521$, la qual va remuntant la vall de Manyanet i que es dirigeix en un primer moment cap a Xerallo. Quasi en arribar al poble, trobarem per l'esquerra la carretereta que es dirigeix cap a l'antiga fàbrica de ciment. Ens caldrà anar cap aquí i en arribar-hi, farem una nova aturada, a poc més de $1 \mathrm{Km}$ de l'anterior.

En aquest tram, hem trobat afloraments d'unes calcàries cretàciques que pertanyen probablement al Garumnià. Tanmateix haurem vist calcàries triàsiques del Muschelkalk. Les hem vist poc abans d'arribar a la fàbrica de ciment. Aquests materials es situen prop del Mantell de Bóixols (situat al sud del nostre recorregut) i el Mantell de les Nogueres (per on farem els trams inicials del recorregut).

A l'indret de l'aturada es troben les instal-lacions de la fàbrica de ciment de Xerallo, un interessant punt del nostre patrimoni miner, que cal protegir i conservar, malgrat ara trobar-se molt malmès. Aquesta fàbrica va subministrar el ciment utilitzat en la construcció de les grans preses dels embassaments d'aigua de la Noguera Ribagorçana. (fotografies 3 i 4).

Pel que fa al combustible, cal fer esment de que s'utilitzava l'extret a les properes Mines de Carbó de Malpàs (Alta Ribagorça). El carbó es transportava d'una vall a l'altra, mitjançant un telefèric miner. Així, prop del poblet de Sentis, es troben restes de d'aquest antic telefèric que transportava el carbó.

Per d'altra banda, des d'aquest indret (i des d'altres del recorregut), mirant cap al SSE, encara es veuen les antigues explotacions de calcàries mesozoiques (del Cretàcic) utilitzades per a l'ús d'aquesta fàbrica. Al respecte, cal dir que es un indret que caldria conservant, recuperant en el possible les antigues instal-lacions mineres, com el telefèric. 


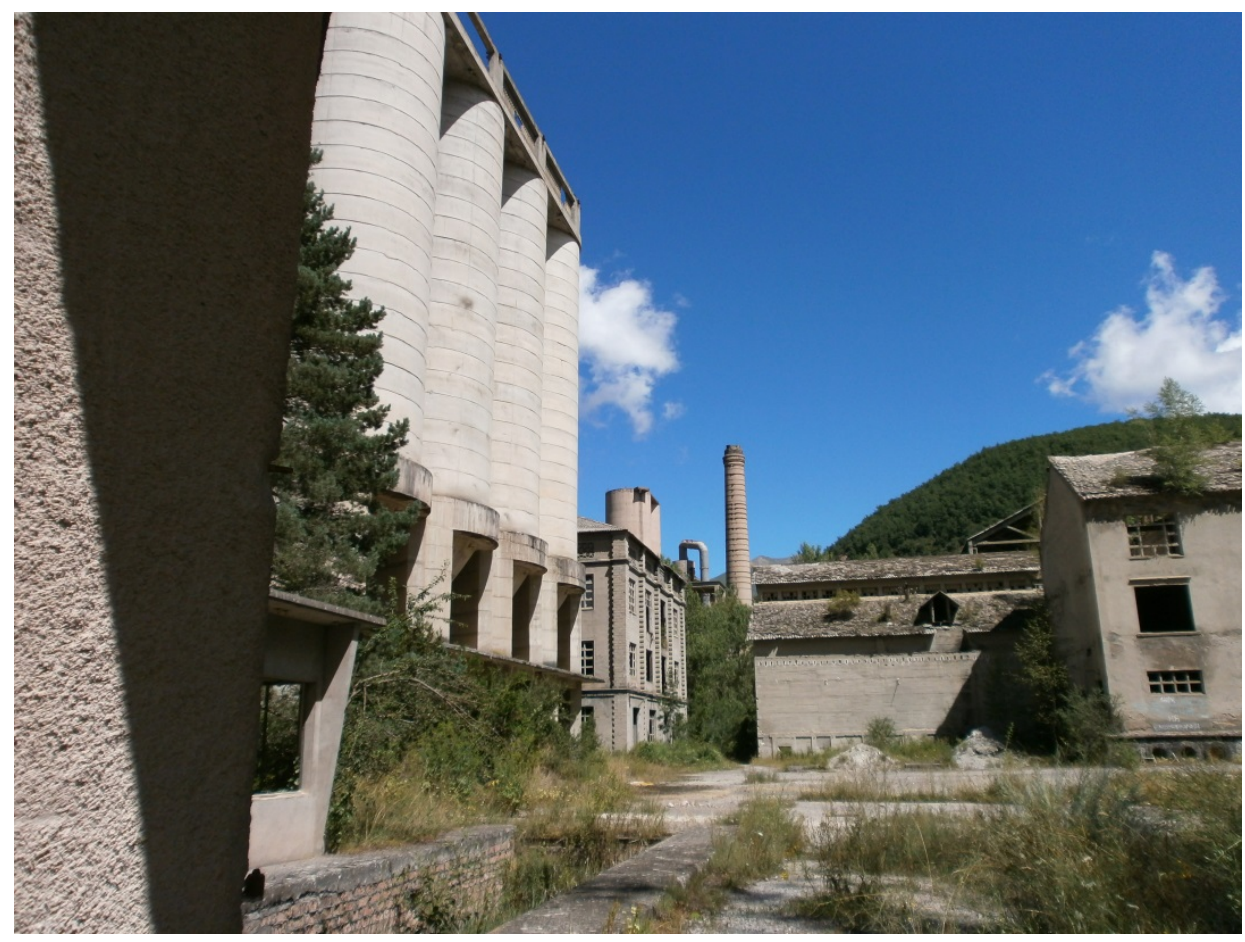

Fotografia 3. Antiga fàbrica de ciment de Xerallo / Agost del 2013

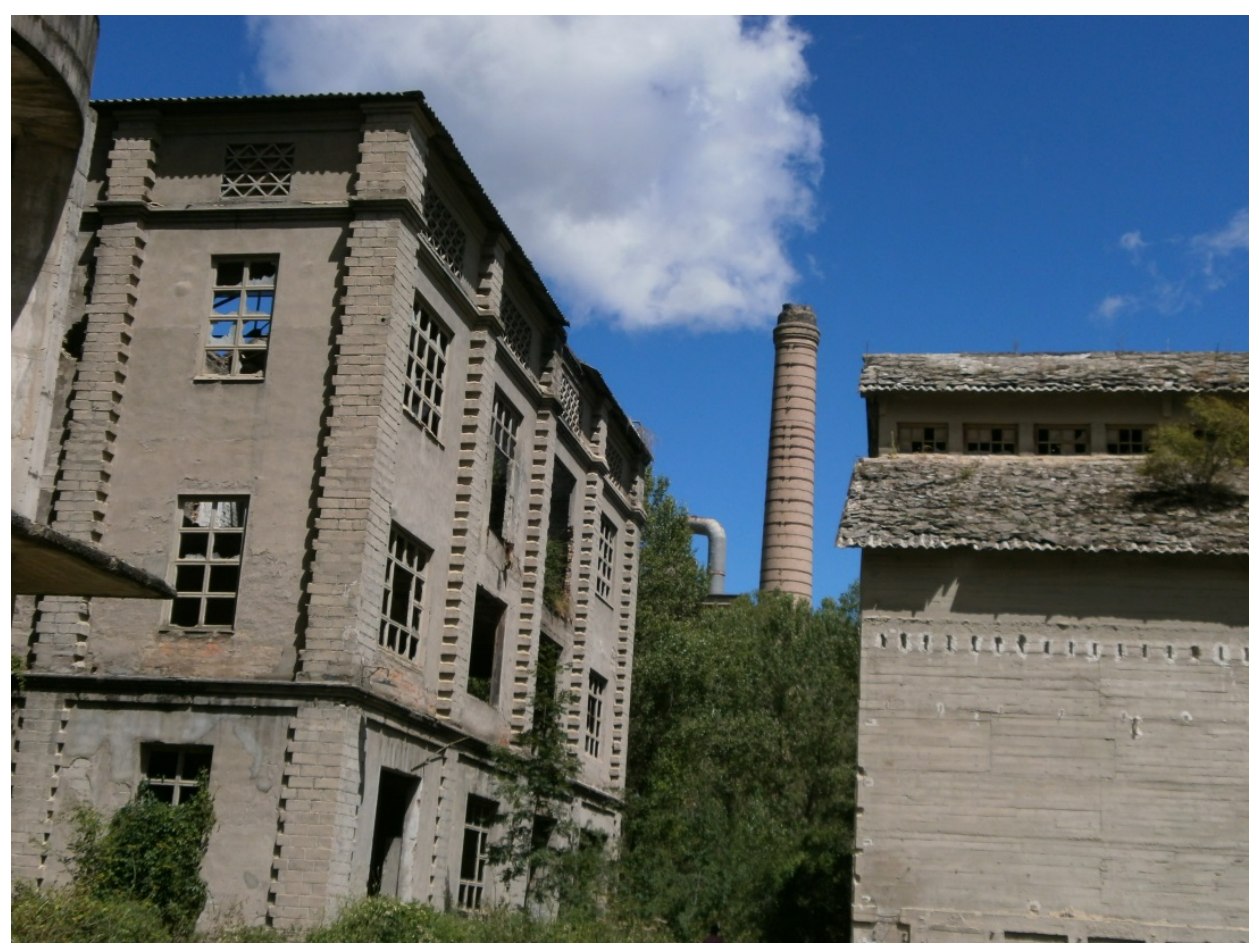

Fotografia 4. Un altre aspecte de I’antiga fàbrica de ciment de Xerallo / Agost del 2013 


\subsection{Parada 5 - CONDICIONAL. ANTIGA PEDRERA PER LA FÀBRICA DE CIMENT DE XERALLO, (Xerallo, actual terme de Sarroca de Bellera de la comarca del Pallars Jussà, i antigament del terme de Benés, de I’Alta Ribagorça). (Full 214).}

Per fer aquesta aturada, no ens cal fer cap desplaçament, ja que I'antiga explotació es visible des de diferents indrets dels voltants de Xerallo.

Efectivament, des d'aquesta indret (i des d'altres del recorregut), mirant cap al SE, encara es veuen les antigues explotacions de calcàries mesozoiques (del Cretàcic) utilitzades per a l'ús d'aquesta fàbrica. Al respecte, cal dir que es un indret que caldria conservant, recuperant en el possible les antigues instal-lacions mineres, com el telefèric.

Aquestes explotacions es troben situades sobre uns afloraments d'unes calcàries mesozoiques que pertanyen al Cretàcic Superior, ubicant-se dintre del Mantell de Bóixols. Per altra banda, la pedrera es troba al límit de les comarques del Palars Jussà i de I'Alta Ribagorça, molt prop del poble de Perbes. S'hi accedeix des de la carretera $N-260$, pujant cap el darrer poble esmentat. (fotografia 5).

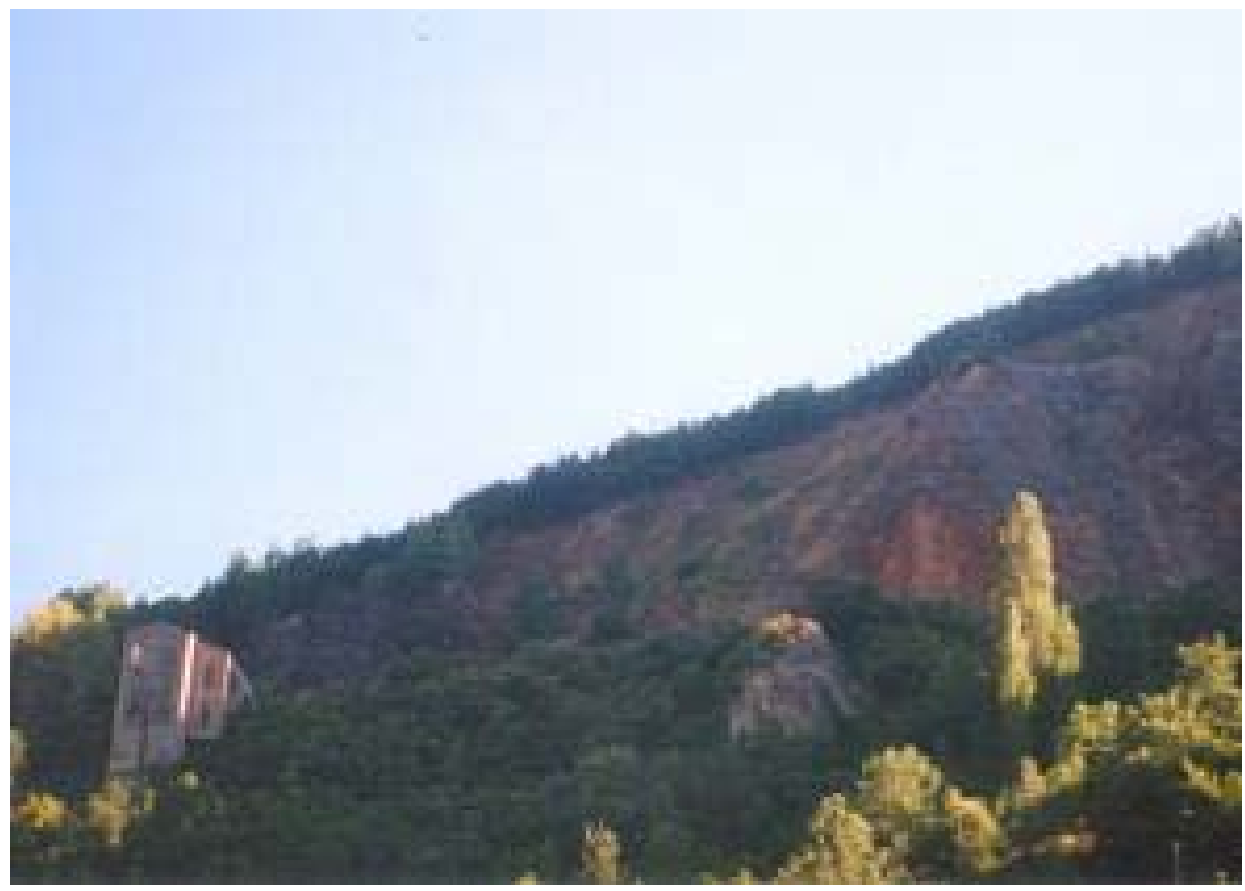

Fotografia 5. La pedrera de la fàbrica de ciment de Xerallo / Maig del 2001 


\subsection{Parada 6. ANTIC POBLAT MINER DE LA FÀBRICA DE CIMENT DE XERALLO, (Xerallo, terme de Sarroca de Bellera de la comarca del Pallars Jussà, i abans del terme de Benés, de l’Alta Ribagorça). (Full 214).}

Des de la parada anterior, cal fer un brevíssim recorregut, tot anant cap al Poblat Miner de la Fàbrica de Ciment de Xerallo. Així haurem fet un nou recorregut molt proper als $0,5 \mathrm{Km}$. $\mathrm{Hi}$ anirem per la carretera $L-521$.

En aquest recorregut, hem trobat afloraments dels materials mesozoics esmentats al trajecte cap a la PARADA 4. Per d'altra banda, també s'han fet palesos afloraments dels materials triàsics del Keuper. Així, en aquest moment, ens trobem situat dintre de la denominada Unitat de les Nogueres, del Sistema Pirinenc.

En aquest indret hi ha un interessant patrimoni, relacionat amb les construccions i amb les vivendes situades prop de I'antiga fàbrica de ciment. També cal fer esment de l'Església situada per sobre d'aquest poblat. (fotografies 6 i 7 )

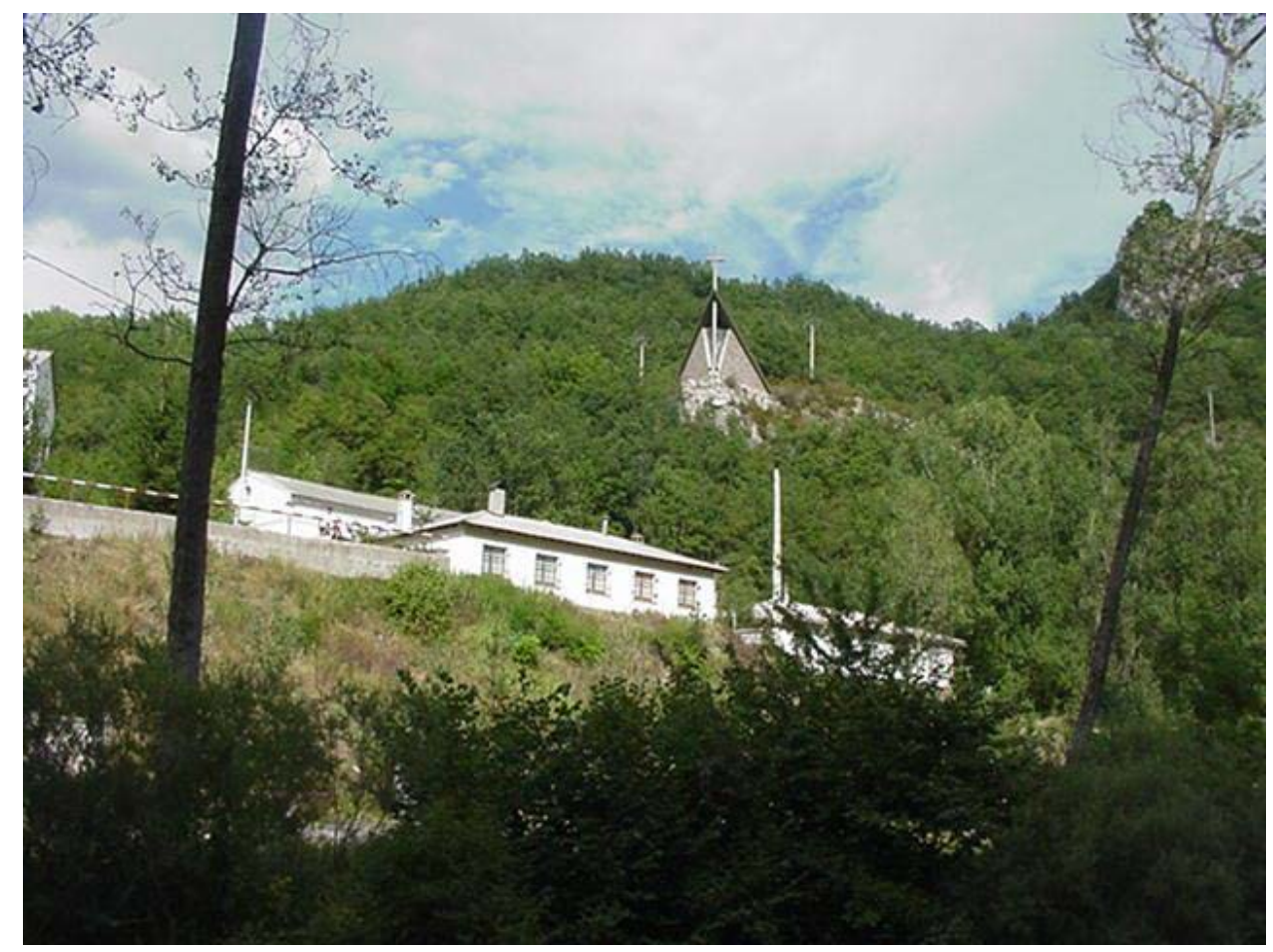

Fotografia 6. El poblat miner de la Fàbrica de Ciment de Xerallo: I'actual poble de Xerallo.

Per sobre, es pot veure l'església / Juny del 2009 


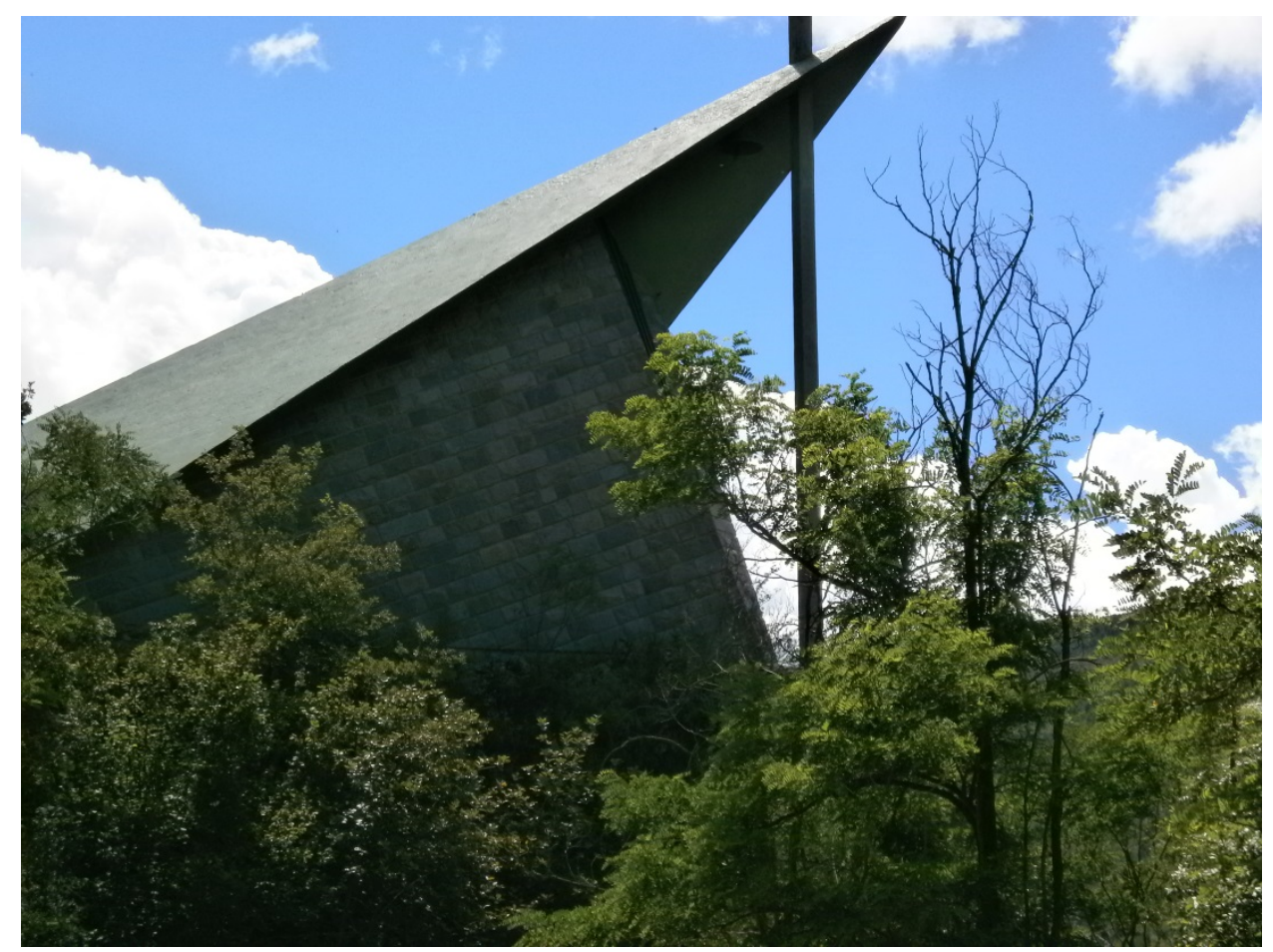

Fotografia 7. L'Església del poblat miner de Xerallo / Agost del 2013

\subsection{Parada 7. ANTIGA PEDRERA DE GRESOS DE LA CARRETERA DE LES ESGLÈSIES, (Xerallo, actual terme de Sarroca de Bellera de la comarca del Pallars Jussà, i antigament del terme de Benés, de l'Alta Ribagorça). (Full 214).}

Després de fer l'aturada anterior, cal fer un altre petit recorregut, per tal d'arribar fins a una antiga explotació de gresos situada a la vora de la carretera. Així, haurem fet un recorregut un xic inferior als 0 ` $5 \mathrm{Km}$. Per anar-hi, utilitzarem de nou la carretera local L - 521 .

En aquest recorregut, efectuat íntegrament dintre de la Unitat de les Nogueres, del Sistema Pirinenc, haurem trobat afloraments dels materials triàsics, fonamentalment del Triàsic Inferior, del Buntsandsteim. Per d'altra banda, en aquest recorregut, hem continuat circulant pel Mantell de les Nogueres, sempre dintre del Sistema Pirinenc. Ens haurem apropat molt a I'Encavalcament de Buira (de direcció clarament pirinenca, de WNW - ESE, aproximadament), però no l'haurem travessat.

En aquest indret es troba un aflorament dels nivells de gresos rogencs, els quals pertanyen al Triàsic Inferior. Aquests materials han estat explotats en aquest indret. Aquests materials han estat emprats a la propera fàbrica de ciment de Xerallo i també a diverses construccions de la zona. (fotografia 8). 


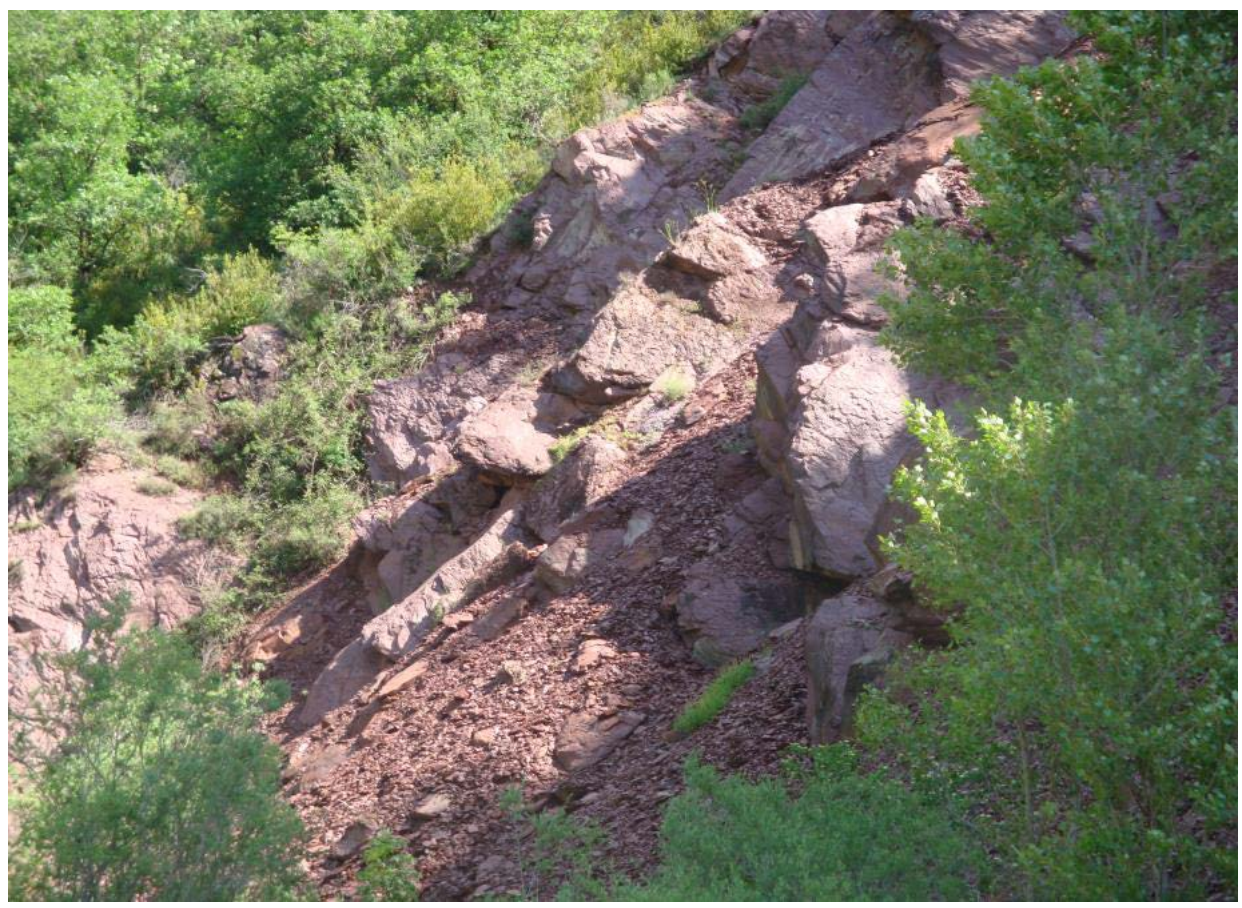

Fotografia 8. Explotació de gresos rogencs del Buntsandsteim, per a la Fàbrica de Ciment de Xerallo Aflorament dels materials del Buntsandsteim / Juny del 2009

\subsection{Paradda 8. CARRETERA A MAÑANET, IMMEDIACIONS DE BENÉS, (Benés, ara del terme de Sarroca de Bellera del Pallars Jussà, i antigament del propi terme de Benés, de l’Alta Ribagorça). (Full 214).}

Després de fer l'aturada anterior, cal fer un altre petit recorregut, per tal d'arribar fins a les immediacions de la Mola d'Amunt, per tal d'anar cap a les immediacions del petit poble de Benes, tot seguint la carretereta que es dirigeix cap a Mañanet. Prop del poble de Benés, ens caldrà fer una nova aturada d'aquest itinerari. Així, haurem recorregut poc més de $5 \mathrm{Km}$.

En aquest tram s'han començat a trobar afloraments dels nivells rogencs del Permo-Tries, amb trams de gresos i calcolutites, fonamentalment. Tot i així, bona part del recorregut, l'haurem efectuat entre els afloraments triàsics del Keuper. Per d'altra banda, hem continuat estant dintre del Mantell de les Nogueres, plenament ubicats dintre del Sistema Pirinenc. Tanmateix, cal dir, que en aquest tram hem travessat I'Encavalcament de Buira, de direcció WNW - ESE, clarament pirinenca.

En aquest lloc es troba un interessant aflorament dels nivells del Permotries en posició gairebé vertical, formant unes boniques "espases". (fotografies 9 i 10). 

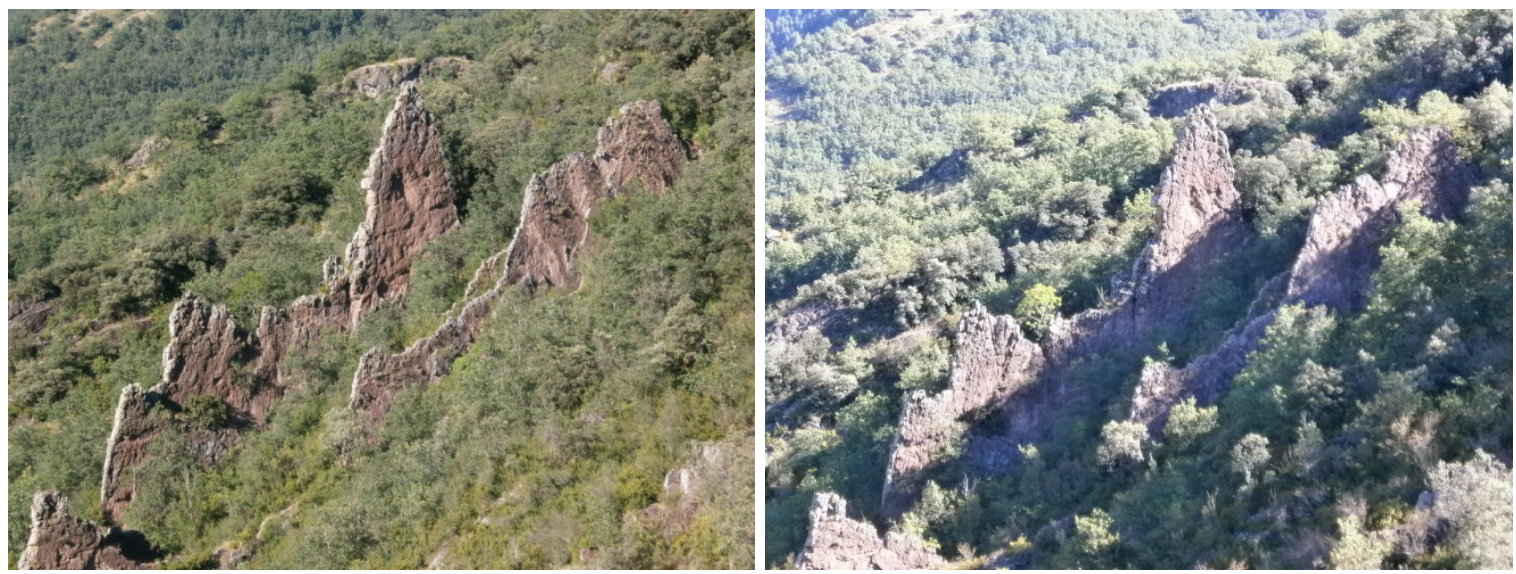

Fotografies 9 i 10. Les "espases de Benes". Hokc-backs formats per nivells del Permotries.

Agost i setembre del 2013

En aquest indret finalitza el recorregut de l'itinerari.

\section{Bibliografia}

GUIMERÀ, J. et altri (1992).- Geologia (II), Història Natural dels Països Catalans, Vol. 2, 547 pag. Enciclopèdia Catalana, S.A. Barcelona.

IGME (1994).- Mapa Geológico de España a escala 1:50.000 (Plan Magna). Fulla i Memòria ${ }^{\circ}$ 252 (Tremp). Inst. GeoMinero y Tecnol. España. Minist. Indústria. Madrid.

MATA-PERELLÓ, J.M. (1991).- Els Minerals de Catalunya. Arxius de la Secció de Ciències de I'Institut d'estudis Catalans, vol.47, 545 pàgines. Barcelona.

MATA-PERELLÓ, J.M. (1995).- Itinerari Geològico-Mineralògic pel Pallars Jussà i pel Pallars Sobirà: des de Puimanyons a Sort. Inèdit, 13 pàgines. Barcelona.

MATA-PERELLÓ, J.M. (1996a).- Selecció d'itineraris geològics i mineralògics per les terres de Lleida. Pub. Museu de Geologia "Valentí Masachs", 72 pàgines. Manresa.

MATA-PERELLÓ, J.M. (1996b).- Itinerari Geològico-Mineralògic per la comarca de la Noguera: des de Bellmunt d'Urgell a Camarasa i al Pas de Terradets, Inèdit, 16 pàgines. Manresa.

MATA-PERELLÓ, J.M. (1998a).- Recorregut de recerca geològica I mineralògica per les comarques de la Noguera I del Pallars Jussà: des de Balaguer a Tartareu, I des d'Ager a Puigcercós. Algeps, sèrie $B, n^{\circ} 89,16$ pàgines. Manresa.

MATA-PERELLÓ, J.M. (1998b).- Recerca geològica I mineralògica per les comarques de la Noguera I del Pallars Jussà: des del Pont d'Alentorn a Vilanova de Meià, I des del Pas Nou al Congost d'Erinyà. Algeps, sèrie $B, \mathrm{n}^{\circ}$ 97, 14 pàgines. Manresa.

MATA-PERELLÓ, J. M. (2000).- Recorregut de recerca geològica i mineralògica per les comarques de I'Alta Ribagorça i de la Val d'Aran: des de Malpàs al Túnel de Vielha, per Pont de Suert. Terra Endins, $\mathrm{n}^{\circ} 18,10$ pàg. Manresa. 
MATA-PERELLÓ, J.M. (2002a).- Recorregut de recerca geològica i mineralògica per les comarques del Pallars Jussà i de l'Alta Ribagorça: des de la Pobla de Segur a Xerallo i al Pont de Suert. Inèdit. 12 pag. Manresa.

MATA-PERELLÓ, J.M. (2002b).- Recorregut de recerca geològica i mineralògica per les comarques del Pallars Jussà i de I'Alta Ribagorça: des de Senterada a Xerallo, la Vall de Manyanet i al Pont de Suert. Inèdit. 12 pag. Manresa.

MATA-PERELLÓ, J.M. (2003).- Recorregut de recerca geològica i mineralògica per les comarques del Pallars Jussà i de l'Alta Ribagorça: des de la Pobla de Segur a Xerallo, Adons i al Viu de Llevata. Inèdit, 8 pag. Manresa.

MATA-PERELLÓ, J.M. (2009).- Recorregut de recerca geològica i mineralògica per les comarques del Pallars Jussà i de l'Alta Ribagorça: des de Senterada a Xerallo i al Pont de Suert. Inèdit. 10 pàgines. Manresa.

MATA-PERELLÓ, J.M. (2010).- Recorregut de recerca geològica i mineralògica per les comarques del Pallars Jussà i de l'Alta Ribagorça: des de la Pobla de Segur a Senterada, Xerallo i al Pont de Suert. Inèdit. 10 pàgines. Manresa.

MATA-PERELLÓ, J.M. (2013).- Recorregut de recerca geològica i mineralògica per la comarca del Pallars Jussà: des de la Pobla de Segur a Senterada, Sarroca de Bellera, a Xerallo i a la Mola d’Amunt. Inèdit. 12 pàgines. Manresa.

MATA-PERELLÓ, J.M. i MATA LLEONART, R. (2000a).- Recorregut de recerca geològica i mineralògica per les comarques de la Noguera i del Pallars Jussà: des del Pas de Terradets a Puigcercós i al Congost d'Erinyà, Terra Endins, nº 15, 10 pàg. Manresa.

MATA-PERELLÓ, J.M. i MATA LLEONART, R. (2000b).- Recorregut de recerca geològica i mineralògica per les comarques del Pallars Jussà i de I'Alta Ribagorça: des de Senterada al Pont de Malpàs, Terra Endins, nº 17, 7 pàg. Manresa.

MATA-PERELLÓ, J. M. i MONTANÉ i GARCÍA, P. (2002).- Recorregut de recerca de geològica i mineralògica per les comarques de l'Alta Ribagorça i del Pallars Jussà: des de la Pressa de Colomers a Malpàs i a la Vall de Manyanet. Inèdit, 12 pag. Manresa.

MATA-PERELLÓ, J.M. i SANZ BALAGUÉ, J. (1993).- Guía de identificación de Minerales, adaptada fundamentalmente a la Península lbérica. Parcir, Edic. Selectas, 243 pàgines. Manresa.

RIBA ARDERIU, O. et altri (1976).- Geografia Física dels Països Catalans. Edit Ketres. 211 pàgines. Barcelona.

ROSELL SANUI, J. (1970).- Explicació del Mapa Geològic, a escala 1:50.000, corresponent al full no 252 (Tremp). Mapa Geológico de España. Inst. Geológico y Minero de España. Madrid. 